\title{
Samuli Hägg
}

\section{Lisää käyttöä mahdollisille maailmoille}

Mahdollisten maailmojen semantiikkaan perustuva kirjallisuudentutkimus on 1970luvulta asti tarjonnut käsitteellisen järjestelmän, jonka avulla kirjallisuutta voidaan katsoa hieman eri tavalla kuin aiemmin. Marie-Laure Ryan kirjoitti kuusitoista vuotta sitten, että olisi parasta, jos mahdollisten maailmojen teorian käsitteet soluttautuisivat eri kulttuuri-ilmiöiden käsittelyyn samalla tavoin kuin Genetten narratologiset käsitteet ovat tehneet. Mahdollisten maailmojen käsitteet ovat Ryanin mukaan analyyttisia työkaluja, joihin ei sisälly "tutkimuksellista ideologiaa" (Ryan 1992, 554). Tällainen soluttautuminen on ollut melko vähäistä, vaikka mahdollisten maailmojen käsitteitä tietysti jonkin verran käytetäänkin niin kirjallisuuden- ja taiteentutkimuksessa kuin muissakin ihmistieteissä.

Kirjallisuudentutkimuksessa mahdollisten maailmojen käsitteitä sovelletaan lähinnä silloin, kun tutkittavassa teoksessa tematisoidaan maailmojen välisiä suhteita tai maailmoilla muuten leikitellään. Tässä artikkelissa pohditaan, voitaisiinko mahdollisille maailmoille keksiä monipuolisempaa käyttöä narratologisessa analyysissa ja tulkinnassa.

Mahdollisten maailmojen semantiikan ${ }^{1}$ käsitteitä hyödyntävää kirjallisuudentutkimusta ei voi ilman muuta pitää narratologian osa-alueena: mahdollisten maailmojen semantiikka on kirjallisuuden tulkintakehys siinä missä muutkin filosofiset suuntaukset. Keskeisimmät kirjallisuudentutkimuksen sovellukset on kuitenkin tehty narratologisen keskustelun piirissä: mahdollisten maailmojen poetiikan² auktoriteetit Lubomír Doležel, Thomas Pavel ja Marie-Laure Ryan ovat kaikki tuotannossaan liittäneet modaalisen logiikan käsitteet nimenomaan kertomuksen teorian kysymyksiin. Mahdollisten maailmojen käsitteleminen narratologian kontekstissa on siis kirjallisuudentutkimuksen historiaa ajatellen perusteltua.

Olennaisempi syy tarkastella mahdollisten maailmojen käsitteitä juuri narratologian kontekstissa on kuitenkin kertomusteorian kiinnostava nykytilanne. "Jälkiklassisen" vaiheen narratologioiden - esimerkiksi luonnollisen, kognitiivisen, feministisen tai diakronisen narratologian - radikaalien uudistushankkeiden rinnalla mahdollisten maailmojen poetiikka on maltillinen kirjallisuusteoreettinen projekti, jolle on vuosien saatossa kertynyt oma kannattajakuntansa, vakiokysymyksensä ja käsitteellinen arsenaalinsa (jälkiklassisen narratologian käsitteestä ks. Herman 1999). Kiinnostavaa mah- 
dollisten maailmojen poetiikassa on juuri se, ettei siinä eksplisiittisesti tarjota uutta kirjallisuuden tai kertomuksellisuuden selitystä tai väitetä, että kerronnan analyysin ongelmat ratkaistaan narratologisen tutkimuksen kontekstualisoinnilla.

Artikkelin perusväite on, että mahdollisten maailmojen poetiikka on järkevää nähdä yhtenä deskriptiivisen poetiikan tutkimustraditiona. Deskriptiivinen poetiikka, jonka keskeisiä edustajia ovat muiden muassa Benjamin Harshav (ent. Hrushovski) ja Brian McHale, tuottaa kuvauksia kertomusten eri ulottuvuuksista ja tarjoaa nämä kuvaukset tulkinnallisen tutkimuksen ja teorian rakentamisen käyttöön. Deskriptiivinen poetiikka ei kuitenkaan esitä olevansa puhdasta kuvausta siitä mielessä, että se ei tukeutuisi mihinkään teoreettisiin kantoihin (ks. Hrushovski 1976, xvi; McHale 1994). Kuten tullaan huomaamaan, mahdollisten maailmojen poetiikka voi tuottaa "johdonmukaista kuvausta" (vrt. Traill 1996, 136) kertomakirjallisuuden maailmojen rakenteista kuitenkin niin, että se on samalla tietoinen omista kirjallisuusteoreettisista lähtökohdistaan ja pyrkimyksistään.

Käsittelen ensin mahdollisten maailmojen narratologista soveltamista yleisesti esittämällä kriittisen katsauksen aiheesta käytyyn tutkimuskeskusteluun. Tämän jälkeen pohdin mahdollisten maailmojen poetiikan hyötyä kohteenani Reko Lundánin romaani Rinnakkain (2004). Romaanin analyysissa keskityn kahteen strukturalistisen narratologian ja mahdollisten maailmojen poetiikan kannalta kiinnostavaan aiheeseen. Ensin tarkastelen Doleželin ajattelun pohjalta kertomuksen intensionaalisia funktioita kerronnan luotettavuuden sekä puheen ja ajattelun esittämisen suhteen. Tämän jälkeen käsittelen Lundánin romaania Ryanin esittämän mahdollisten maailmojen moninaistumista ja kerrottavuutta koskevan hypoteesin kannalta.

\section{Mahdollisten maailmojen poetiikan haasteita ja painotuksia}

Ihmiset eivät tarvitse romaaneja tai ylipäätään mitään kertomuksia luodakseen mahdollisia maailmoja. Saul Kripken $(1980,44)$ kuuluisan lauseen mukaan "mahdolliset maailmat määritellään, niitä ei löydetä tehokkailla kaukoputkilla". Tämä koskee niin loogikoita kuin muitakin ihmisiä: sekä modaalilogiikan esimerkkimaailmat että maallikoiden ajattelemat uskomus-, toive- tai pelkomaailmat ovat yksinkertaisesti ja vähällä vaivalla määriteltäviä kokonaisia maailmoja. Toista on kaunokirjallisuuden fiktiivisten maailmojen kanssa. Niissä on otettava huomioon kaunokirjallisen tekstin tarjoama tieto ja sen aiheuttamat yksityiskohtaiset rajoitukset, ja toisaalta on yhtaikaa kärsittävä ja nautittava tekstiin väistämättä ujuttautuneista epämääräisyyksistä. Lisäksi on pohdittava, miten tekstissä tarjoiltu tieto pitäisi suhteuttaa tietoon oikeasta maailmasta. Tämä on mahdollisten maailmojen semantiikkaan perustuvan kirjallisuudentutkimuksen ensimmäinen haaste: selvittää, mitä erityistä on juuri kirjallisuuden, vieläpä tiettyjen teosten, tavassa synnyttää mahdollisia maailmoja tai niitä muistuttavia rakenteita. 
Toisaalta ihmiset eivät tarvitse mahdollisten maailmojen semantiikkaa ymmärtääkseen kaunokirjallisuuden maailmoja. Tämä koskee niin kirjallisuudentutkijoita kuin muitakin ihmisiä. "Maailma" on - kuten "kertomus", "henkilö" tai "vuoropuhelu" - intuitiivisesti kirjallisuuteen ja sen ymmärtämiseen yhdistyvä arkikäsite tai metafora, eikä modaalilogiikan käsitteen "mahdollinen maailma" huomioiminen ratkaisevasti muuta tapaamme suhtautua kirjallisuuteen. Tämä on mahdollisten maailmojen semantiikkaan perustuvan kirjallisuudentutkimuksen toinen haaste: selvittää, mitä teoreettista lisäarvoa saadaan mahdollisten maailmojen semantiikan käsitteiden yhdistämisellä kirjallisuudentutkimukseen.

Mahdollisten maailmojen poetiikassa on pohdittu laajasti jälkimmäistä näistä haasteista. Erityisesti kysymys filosofian mahdollisten maailmojen ja kirjallisuuden fiktiivisten maailmojen erilaisuudesta ja samuudesta on saanut huomiota teoreettisissa esityksissä (Doležel 1979, 1998; Pavel 1986; Ryan 1991, 2000, 2006; Ronen 1994) ja katsauksissa (Ryan 1992, Koskimaa 1999 ja Hägg 2005 ovat tyypillisiä esimerkkejä). ${ }^{3}$ Kuten narratologiakin, mahdollisten maailmojen poetiikka on suurelta osin ollut toisen asteen poetiikkaa, metodologista keskustelua tuollaisen poetiikan mahdollisuudesta (vrt. Jedličková 2006, 258-259). Tämä keskustelu jatkuu narratologipiireissä edelleen, mistä osoituksena vaikkapa parin vuoden takainen Style-lehden tsekkiläiselle fiktion maailmojen tutkimukselle omistettu erikoisnumero (Style 40:3). Monet sen artikkeleista käsittelevät metanarratologisesti Prahan strukturalismin perinnön, modaalilogiikan ja strukturalistisen narratologian suhteita. Myös muissa kertomuksen tutkimukseen erikoistuneissa lehdissä - Poetics Today, Narrative - julkaistaan edelleen artikkeleja, joissa mahdollisten maailmojen poetiikan mahdollisuutta pohditaan (esim. Klaver 2006, Ryan 2006).

Mahdollisten maailmojen poetiikan ensimmäisen haasteen - siis erityisten kirjallisten maailmanluomiskeinojen selvittämisen - kannalta kiinnostavimmat saavutukset ovat sellaisia, joissa modaalilogiikan mahdollisten maailmojen kontekstista siirrytään rohkeasti kirjallisuudentutkimuksen kysymyksenasettelujen pariin, ja ongelma modaalilogiikan ja kirjallisuudentutkimuksen yhdistämisestä hyllytetään taktisesti. Tässä suhteessa johdonmukaisimpia pitkälle kehitellyistä mahdollisille maailmoille perustuvista esityksistä ovat Ryanin Possible Worlds, Artificial Intelligence, and Narrative Theory (1991) ja Doleželin 1970-luvulta alkanut teoreettinen tutkimus, jonka tulokset on koottu uudistetussa muodossa hänen teokseensa Heterocosmica (1998). Lisäksi David Hermanin Story Logic (2002) on kokonainen kertomuksen teoria, joka osin hyödyntää mahdollisten maailmojen semantiikkaa. ${ }^{4}$

Mark Currie (2008, 28) moittii kirjallisuudentutkimusta rajoittumisesta tutkimaan sitä, miten teokset ilmiselvästi - temaattisella tasolla - käsittelevät kerronnan ja ajan ongelmaa. Sen sijaan aika kaiken kirjallisuuden rakenteellisena piirteenä on 
jäänyt vähemmälle huomiolle. Currien lääke tähän ongelmaan on se, että analyysiin "päästetään takaisin tietty määrä formalismia”. (Mp.) Fiktion maailmojen tutkimuksen suhteen tilanne on koko lailla samankaltainen. Olisi kuitenkin kohtuutonta arvostella tutkijoita, jotka tarkastelevat maailmoja kirjallisuuden sisältöinä tai teemoina. Fiktion maailmoja on kiinnostavaa tutkia painottaen ainakin kolmea eri aspektia.

Ensimmäinen painotus on tematisoiva ja tulkinnallinen. Mahdollisten maailmojen semantiikka on tulkinnallinen kehys siinä missä muutkin filosofiset suuntaukset tai kulttuuriteoriat. Tämä sovellustapa on kirjallisuudentutkimuksen kannalta yleisin ja intuitiivisesti kiinnostavin. Kaunokirjallisuus luo (useimmiten) fiktiivisiä maailmoja ja näyttää lukijoilleen reaalimaailmankin uudella tavoin, ja monet kirjalliset tekstit lisäksi tematisoivat todellisia ja fiktiivisiä maailmoja ja niiden välisiä suhteita. Postmodernistinen kirjallisuus on tässä suhteessa edustava esimerkki. McHalen (1988, 1993) tutkimukset ovat osoittaneet postmodernismin korostavan maailmojen välisiä suhteita ja ylipäätään ontologisia kysymyksiä. ${ }^{5}$ Myös Linda Hutcheon (1996) on yhdistänyt kiinnostavasti postmodernististen romaanien tyypillisesti monimutkaiset ja ristiriitaiset fiktiiviset maailmat mahdollisten maailmojen teorian maltilliseen näkemykseen merkityksenmuodostuksesta, johon ei sisälly jälkistrukturalistista merkityspakoisuutta. Myös fantastisia elementtejä sisältävä kirjallisuus on sisällöllisesti ja teemojensa puolesta luontevaa tarkastella mahdollisten maailmojen käsitteiden avulla. Tämän on osoittanut Nancy H. Traill (1996, 11-20) laatimalla typologian fantastisen kirjallisuuden maailmojen kuvaamista varten. Mahdollisten maailmojen semantiikka on erityisen sovelias tulkinnallinen kehys juuri maailmojen suhteita tematisoivan kirjallisuuden käsittelyssä. ${ }^{6}$

Toinen painotus on niin ikään tulkinnallinen, mutta korostaa kirjallisuuden ja mahdollisten maailmojen teorian vuorovaikutusta. Tästä näkökulmasta kirjallisuus itse kokeilee ja työstää mahdollisten maailmojen teoriaa. Tämä sovellustapa vie mahdollisten maailmojen soveltamisen askelen pidemmälle, ja kokeellisen kirjallisuuden voi katsoa toimivan mahdollisten maailmojen semantiikan kokeilun kenttänä. Elizabeth Klaverin artikkeli "Possible Worlds, Mathematics, and John Mighton's Possible Worlds" (2006) on tästä havainnollinen esimerkki. Artikkelissaan Klaver osoittaa, miten John Mightonin näytelmä Possible Worlds käsittelee peitetysti mahdollisiin maailmoihin liittyviä teoreettisia ongelmia. ${ }^{?}$

Kolmas painotus, tässä artikkelissa eniten käsitelty, on menetelmällinen: mahdolliset maailmat ja niihin liittyvät käsitteet tarjoavat kirjallisuudentutkijoille analyyttisia välineitä. Tällaiseen lähestymistapaan viittasi Ryan jo mainitussa ennustuksessaan, joka on tässä laajempana:

Uskon, että mahdollisten maailmojen teorian tutkimuksen markkinoille tuomat ideat ovat parhaiten hyödyksi, jos niiden annetaan soluttua eri kulttuu- 
ri-ilmiöiden eri näkökulmista tapahtuvaan käsittelyyn, samalla tavoin kuin Genetten koulun narratologiset käsitteet soluttuivat useimmille tutkimusaloille ja lopulta levisivät tieteidenväliseen diskurssin tutkimukseen. Mahdollisten maailmojen teoria ei tarjoa tutkimuksellista ideologiaa vaan kokoelman analyyttisia työkaluja, joita voi soveltaa monilla eri aloilla moniin eri tarkoituksiin. (Ryan 1992, 554.) ${ }^{8}$

Ryan on itse tuottanut joukon tällaisia työkalukäsitteitä. Tässä artikkelissa fiktion maailmasta tai fiktiivisesti todesta maailmasta puhuttaessa tarkoitetaan Ryanin $(1991,22)$ käsitettä textual actual world. Fiktion osamaailmasta puhuttaessa tarkoitetaan fiktiivisesti toden maailman suhteen saavutettavaa mahdollista maailmaa, textual actual possible world. Tällainen osamaailma on esimerkiksi henkilöhahmon yksityinen maailma.

Toisin kuin Ryan väittää, mahdollisten maailmojen semantiikka kuitenkin tarjoaa analyyttisten käsitteiden lisäksi myös oman tutkimuksellisen ideologiansa. Ideologinen vire on näkyvissä Pavelin tavassa aloittaa teoksensa Fictional Worlds (1986), ensimmäinen kirjanmittainen fiktion mahdollisia maailmoja käsittelevä tutkimus. Pavel kommentoi voimakkaasti strukturalistisen narratologian vähäistä kiinnostusta kaunokirjallisuuden semanttista ulottuvuutta kohtaan: "Vapauduttuaan tekstuaalisen lähestymistavan rajoituksista fiktion teoria voi jälleen vastata mielikuvituksen maailmojen luomisvoimaan ja käsitellä sepitteellisen olemassaolon ja maailmojen ulottuvuuksia.” (Pavel 1986, 10.) Doleželin (1983, 511-512) uskoa mahdollisten maailmojen teoriaan voi pitää yhtä vahvana: "Kaikki perinteiset kirjallisuuden merkityksen ongelmat voidaan muotoilla uudestaan [mahdollisten maailmojen] teorian metakielellä. Lisäksi tämä lähestymistapa paljastaa kirjallisuuden semanttisia aspekteja, joita ei tähän mennessä ole huomattu tai joille ei ole annettu niiden ansaitsemaa merkittävyyttä".

Vaikkei "tekstuaalista lähestymistapaa" Pavelin ja Doleželin teorioissa ollakaan tyystin hylkäämässä, polttopistettä siirretään rakenteista tekstin ja todellisten ja kuviteltujen maailmojen suhteisiin. Mahdollisten maailmojen poetiikka muodostaa johdonmukaisen tutkimuksellisen uskomus- ja käsitejärjestelmän (eli teorian). Tuossa järjestelmässä korostetaan yhtälätä kirjallisuuden maailmoja luovia ominaisuuksia, toisaalta maailmojen ja merkitysten tekstuaalisia perusteita. Tällainen on mahdollisten maailmojen deskriptiivisen poetiikan tutkimuksellinen ideologia. Käytännön kirjallisuudentutkimuksen kannalta kiinnostava kysymys on se, miten tämän poetiikan käsitteitä voitaisiin konkreettisesti hyödyntää yksittäisten teosten tutkimuksessa. Tarkastelen tätä kysymystä seuraavassa luvussa Reko Lundánin Rinnakkain-romaanin yhteydessä.

\section{Mahdolliset maailmat Rinnakkain}

Rinnakkain on Reko Lundánin (1969-2006) toinen romaani. Se käsittelee 37-vuotiaan miehen rivitaloasumista, parisuhdekriisiä ja loppuunpalamista. Romaanin minäkertoja ja päähenkilö Jarmo Koponen on naimisissa oleva helsinkiläinen työvoimaneuvoja ja 
kahden lapsen isä. Lundánin teos käsittelee toisiinsa lomittuvia kriisejä, jotka liittyvät parisuhteeseen, yhteisöön kuulumiseen ja yksilöidentiteetin ylläpitämiseen. Koposen parisuhde joutuu koetukselle, kun hänen Kirsi-vaimonsa saa EU-viran ja muuttaa Brysseliin ja päähenkilö itse ihastuu lähiseudulla työskentelevään nuoreen naiseen. Rivitaloyhteisöelämä monimutkaistuu, kun taloyhtiön saunasta löytyy hometta ja naapuritontille rakennetaan asunnottomien tukikoti. Lopulta Koponen sairastuu psyykkisesti.

Romaani tematisoi rinnakkaisuutta monin tavoin. Helsinkiläisen rivitaloyhteisön asujien yksilölliset ja yhteisölliset pienoiskriisit kestävät yhtä pitkään kuin Yhdysvaltain avoimet sotatoimet Irakissa; maailmanpolitiikka asetetaan näin rinnan yksilö- ja naapurustotason kanssa. Keskiluokkainen asuntoyhteisö on rinnakkain asunnottomien tukikodin kanssa, minkä lisäksi rivitalossa naapurit ovat tietysti konkreettisesti rinnakkain. Aviopuolisot elävät yhdessä mutta lopulta henkisesti erillään, rinnakkain. Monet Lundánin romaanin rinnakkaisuuksista voi nähdä myös rinnakkaisten maailmojen suhteina. Yhtäältä romaanin henkilöiden yksityiset toiveiden, pelkojen ja fantasioiden voi katsoa muodostavan fiktion osamaailmoja; toisaalta myös romaanin yhteisöjen vastakkain asetetut pyrkimykset voi kuvata keskenään vaihtoehtoisina maailmoina. Lundánin tekstin analysointi mahdollisten maailmojen poetiikan käsittein vaikuttaa siis ainakin lähtökohtaisesti lupaavalta. Lundánin teosta ei voi kuitenkaan pitää kaunokirjallisena modaalilogiikan harjoitelmana: maailmat tai fiktion ontologiset tasot eivät ole teoksen keskeistä tematiikkaa tai muuten ilmeisen pohdiskelun kohteena. Kuinka hyödyllinen mahdollisten maailmojen poetiikan käsitteistö on tulkittaessa kirjallisuutta, joka ei ilmiselvästi käsittele maailmojen suhteita?

Doleželin mukaan mahdollisten maailmojen poetiikka eli "narratiivinen semantiikka” on sisäisesti kaksijakoista: yhtaikaa hermeneuttista ja formalistista. "Narratiivinen semantiikka ei väitä, että esteettinen vaikutus syntyisi 'puhtaista' muodoista. Sen lähde on pikemmin kirjallisen teoksen kokonaisuudessa[.] Merkityksen formaali perusta takaa tekstin merkityksen objektiivisuuden (eli intersubjektiivisuuden). Narratiivisen semantiikan tehtävä on paljastaa ja formuloida kertovien tekstien sisäinen merkitys." (Doležel 1979, 193.) Tekstin ja maailmojen suhteita käsitellessäänkin mahdollisten maailmojen poetiikka on tekstisidonnaista tutkimusta. Lisäksi sen käsitystä tekstistä ja merkityksenmuodostuksesta voi pitää sangen konservatiivisena. ${ }^{9}$ Doleželin hahmotus kirjallisesta viestinnästä (tai välittymisestä; "literary transduction") on osoitus tästä. Hänen mukaansa lukijan tulkinnallinen rooli on toki aktiivinen, mutta tekstin tuottajan ja itse tekstin painoarvo kirjallisen teoksen viestinnässä on suurempi. Kirjailijan luoma teksti rajoittaa lukijan vapautta: "Individualistinen lukemisen etiikka [joka mahdollistaa tekstien lukemisen miten vain] ei ole lukemisen teoria" (Doležel 1998, 205).

Doležel kutsuu kirjallisten tekstien tapoja rakentaa fiktiivisten maailmojen eri puolia intensionaalisiksi funktioiksi. Maailman ekstensionaalinen rakenne (maailma, sen 
jäsenet ja niiden ominaisuudet) voitaisiin kuvata monin eri tavoin ja sanoin, mutta kaunokirjallisessa teoksessa näistä tavoista ja sanoista on valittu juuri tietyt. Fregen käsittein ilmaistuna parafraasin ja kaunokirjallisen teoksen maailmojen ja sen jäsenten Bedeutung on sama, mutta Sinn eri. Kirjallisuudelle tyypillisten maailmantekotapojen analyysi - kirjallisuuden erityisyyden tutkiminen - on mahdollisten maailmojen poetiikan tehtävä. Bohumil Fořt $(2006,190)$ viittaa tähän samaan tehtävään todetessaan Kripkeä parodioiden, että "kertovan diskurssin fiktiivisiä maailmoja voidaan, ainakin metaforisessa mielessä, katsoa (ehkä jollakin tehokkaalla kaukoputkella)". Kertova teksti on mahdollisten maailmojen poetiikan näkökulmasta kirjallisuuden lukijan kaukoputki.

Doleželin $(1998,139)$ mukaan intensionaalisten funktioiden toimintaa tutkitaan tarkastelemalla kertomuksen "tekstuaalisia säännönmukaisuuksia". Kertojan tapaa luoda fiktiivinen maailma olisi siis katsottava kokonaisuutena, jotta sen intensionaalisesta rakenteesta päästäisiin selville. "Tekstuaalisten säännönmukaisuuksien” tutkimisen voisi analyyttisesti jakaa (ainakin) kahtia. Yhtäältä minäkertojan määrittelemän fiktiivisen maailman tai fiktiivisten maailmojen kokonaisuuden tarkastelussa on otettava huomioon kertovan tekstin lineaarisuus ja lukemisen dynaamisuus. Lukijoina saamme tietoa maailmasta vähä vähältä tekstin määrittämässä järjestyksessä, ja fiktiivisen maailman määrittyminen on prosessuaalista ja horisontaalista (ks. Fořt 2006, 194; Rantala 1990, 41). Toisaalta tekstuaalisia säännönmukaisuuksia voi tarkastella vertikaalisesti, tutkimalla fiktiivisen maailman ja sen suhteen saavutettavien maailmojen runsautta ja suhdetta toisiinsa tietyssä kertomuksen vaiheessa.

Doležel hahmottelee kaksi fiktiivisen maailman intensionaalista funktiota: todentamisen ja saturaation funktiot, ja toteaa funktioita varmasti olevan enemmänkin. Todentaminen koskee sitä, mitä fiktiivisessä maailmassa on, saturaatio sitä, kuinka tiheästi tuo maailma on kansoitettu. Kertojahahmon ominaisuudet ovat ilmeisen olennaisia todentamisen funktion kannalta. Doleželin (1998, 148-154) mukaan kolmannen persoonan kertojaan ( $E r$-form) suhtaudutaan luotettavana fiktiivisen maailman määrittelijänä, kun taas minäkertoja (Ich-form) joutuu todistamaan kyvykkyytensä maailman tekijänä. Fiktion maailman todentamisen tutkiminen on siis kertojan luotettavuuden, narratologisen ikuisuuskysymyksen, arviointia mahdollisten maailmojen poetiikan näkökulmasta.

Todentamisen funktion tarkastelu tuo esiin mahdollisten maailmojen poetiikan tavan ratkaista ongelma tekstin ja vastaanottoprosessin painoarvosta analyysin kohteena. Yhtäältä todentamisen funktio ohjaa tutkijan suhtautumaan kertojan luotettavuuteen vastaanoton näkökulmasta: lukija arvioi kertojan "ansiot" maailman määrittelijänä ja tekee lopulta päätelmänsä. Mahdollisten maailmojen poetiikan tekstisidonnainen tutkimusideologia näkyy kuitenkin Doleželin tavassa liittää todentaminen tiettyihin 
prototyyppisiin kertojatyyppeihin. Luotettavuuden arvioinnin painopisteen osittainen siirtyminen tekstin rakenteista lukijan tai lukijayhteisön ominaisuuksiin muistuttaa tapaa, jolla monet narratologit ovat lähestyneet kysymystä viime aikoina. Ansgar ja Vera Nünningin sekä Greta Olsonin näkemykset kertojan epäluotettavuudesta ovat niin ikään sidoksissa sekä tekstin piirteisiin että tekstin oletettuun vastaanottoon (ks. Nünning 2004; Olson 2003, 97-98, 104-105; kattava katsaus keskusteluun artikkelissa Miettinen 2005).

Rinnakkain-romaanin minäkertoja on kiinnostava todentamisen funktion kannalta. Jarmo Koposen kertomuksessa on runsaasti epäluuloa herättäviä aineksia. Kertoja valehtelee ja pohtii avoimesti valehtelunsa lisääntymistä ja henkistä ryhdittömyyttään. Myös runsaahko alkoholinkäyttö, unettomuus, masennus ja siihen liittyvä mielialalääkkeiden käyttö asettavat Koposen kertomuksen kyseenalaiseksi. Romaanin aloitus toimii lukuohjeena siihen, miten minäkertojaan ja hänen määrittelemäänsä maailmaan tulisi suhtautua. Koponen nukahtaa illanvietossa, havahtuu hereille mutta teeskentelee nukkuvaa kuullakseen, mitä hänen vaimonsa ja ystävänsä hänestä puhuvat.

Lauri kysyi, mitä Kirsi tarkoitti. Kirsi vastasi, että sitä oli vaikea kuvata. En ollut läsnä vaikka olinkin paikalla.

Oli outoa kuulla omista ongelmistaan toisen kertomana. Tuntui, että niistä tuli suurempia niin. Vasta nyt todellisia, kun toinen sanoi ne ääneen. [--]

Onneksi Kirsi oli huomannut vain unettomuuden, en ollut puhunut ahdistuskohtauksista mitään. (Lundán 2004, 14.)

Kertojahahmon toiminnassa ja ajattelussa eri tasoilla kertautuva epäluotettavuus ja sen reflektointi kehottavat lukijaa olemaan varuillaan. Rinnakkain-romaanissa lukija tehdään nautittavalla tavalla tietoiseksi tulkintatyöstä, jonka avulla lukija punnitsee, mikä Koposen kerronnassa on valhetta, mikä valehtelusta puhumista ja mikä (fiktiivisesti) totta.

Yksilöpsykologinen kertojan ominaisuuksien arviointi on kuitenkin riittämätön perusta kerronnan luotettavuuden arvioinnille. Kertojahenkilön arviointi nojautuu voimakkaasti antropomorfiseen tulkintaan, jossa tekstuaalisia rakenteita tarkastellaan kuin oikeita ihmisiä (vrt. Culler 1988, 206; Fludernik 2001, 634-635). Tunnetusti epäluotettavatkin kertojat kuitenkin pystyvät todentamaan jonkinlaisen fiktiivisen maailman: lukija ei voi pitää kaikkea totuudesta lipsuvan kertojan kertomaa epätotena (ks. Ryan 1991, 113; Hägg 2005, 126-127).

Mahdollisten maailmojen poetiikan ajatus fiktiivisen maailman vähittäisestä todentamisesta kerronnan keinoin tarjoaa tässä suhteessa uusia luotettavuuden kuvaamisen näkökulmia. Kun romaanin kerronnan katsotaan synnyttävän lukijan tulkinnassa kokonaisen fiktiivisen todellisuuden osamaailmoineen, kertojan luotettavuutta voidaan tarkastella eri maailmoiden välisinä suhteina ja päällekkäisyyksinä. Koposen tapaisten kertojien luotettavuuden antropomorfinen arviointi täydentyy kerronnan synnyttämi- 
en fiktiivisten maailmojen yhteyksien ja ristiriitojen tarkastelulla.

Muiden muassa Olson (2003), Shlomith Rimmon-Kenan (1983, 100-103) ja James Phelan $(2005,49-53)$ ovat osoittaneet monia eri syitä sille, miksi kertojat voivat olla epäluotettavia: muun muassa tietämättömyys, epärehellisyys, kognitiiviset rajoitukset, asenteelliset vinoumat aiheuttavat kerronnan epäluotettavuutta. Mahdollisten maailmojen poetiikan näkökulmasta nämä syyt tuottavat eri tavoin fiktiivisestä todellisuudesta eroavia osamaailmoja: tietämättömyysmaailma, valhemaailma, asennemaailma ja niin edelleen. Myös epäluotettavuuden ilmeisyys vaihtelee. Selvissä tapauksissa fiktiivisesti epätodet ja fiktiivisesti todet maailmat voivat pysyä erillisinä, eikä lukijalla ole vaikeuksia erottaa kertojan poikkeamia fiktiivisestä totuudesta. Vähemmän ilmeinen kerronnan epäluotettavuus on kuitenkin tulkinnallisesti kiinnostavampaa. Epämääräinen epäluotettavuus on maailmalliselta rakenteeltaan samanlainen kuin Traillin määrittelemä fantastisen kirjallisuuden epämääräinen tai monitulkintainen muoto (ambiguous mode), jossa yliluonnollinen maailma ja luonnollinen maailma voivat olla vuorovaikutuksessa keskenään sillä seurauksella, että lukijalle jää lopulta epäselväksi, mikä on totta ja mikä ei fiktiivisessä maailmassa.

Yksi Rinnakkain-romaanin keskeisistä juonellisista jännitteistä koskee kertojan ja tukikotiyhdistyksen Siljan lyhyttä romanttista seikkailua. Lukija totutetaan kertojan Siljaa koskeviin fantasioihin koko romaanin ajan (esim. Lundán 2004, 27, 79, 133, 137, 181). Kertojan ja Siljan ainoa seksuaalinen kohtaaminen kuvataan lopulta lyhyesti mutta kertojan fantasioita noudattelevalla tyylillä (Lundán 2004, 148). Lukijan tehtäväksi jää arvioida kohtauksen todellisuuden aste, tähän ei mahdollisten maailmojen poetiikka tarjoa välineitä. Rinnakkain-romaanin fiktiivisiä maailmoja voisi kuitenkin Silja-kysymyksen suhteen kuvata Traillin mallia mukaillen seuraavasti:

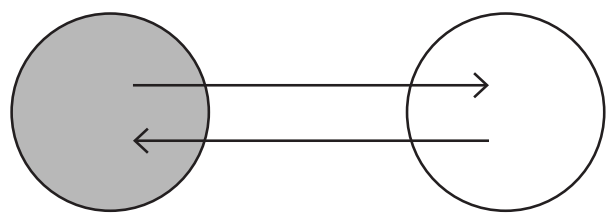

Koposen fantasiamaailma: Koponen \& romanttiset seikkailut Siljan kanssa.
Fiktiivinen todellisuus Koponen \& ahdistus ja kriisi.

Romaanin kerronta ei tarjoile fantasiamaailmaa ja ikävää todellisuutta selkeästi erotettavina osa-alueina. Sen sijaan fantasiamaailma ja fiktiivinen todellisuus vuotavat tapahtumia toisiinsa. Tästä on hyvä esimerkki juuri seksikohtaus, jossa on läsnä sekä eroottisten toiveiden (mahdollinen) toteutuminen että fiktiivisen todellisuuden sekaannus ja ahdistus. Rinnakkain-romaanin kerronnassa todennettava fiktiivinen todellisuus ei 
ole yksinkertaisesti fiktiivisesti totta tai epätotta, vaan siinä on enemmän ja vähemmän epäilyttäviä alueita. Ne on mahdollisten maailmojen poetiikan käsittein mahdollista kuvata fiktiivisesti toden ja sille vaihtoehtoisten "epäluotettavuuden maailmojen" vuoto- tai kosketuskohtina.

Huomion kiinnittäminen fiktiivisen todellisuuden ja sitä ympäröivien maailmojen todentamisen intensionaaliseen funktioon mahdollistaa suhteellisen hienojakoisen kuvauksen romaanikerronnan luotettavuudesta. Siirrytään tarkastelemaan Lundánin kerronnan intensionaalisuutta toisen narratologisen suosikkiaiheen näkökulmasta. Mitä uutta annettavaa mahdollisten maailmojen poetiikalla voisi olla puheen ja ajattelun esittämisen analyysille? Muistetaan Doleželin opetus tekstien intensionaalisen rakenteen selvittämisestä ja tutkitaan nyt yhtä tekstin säännönmukaisuutta, typografista sellaista.

Lundánin romaanin kerronnassa kertoja-päähenkilön sisäinen maailma tuntuu jakautuneen kahtia. Tämä on osoitettu tekstissä myös typografisin keinoin. Koposen kertojahahmon "toinen ääni” on merkitty kursiivilla. Kursivoidut tekstinosat ovat jonkinlaista muun kertovan tekstin kommentointia, joskus kysymysten tai vastaväitteiden muodossa:

Elokuun alkaessa olin jo luullut, että pelastuisin, kohta alkaisi uusi työvuosi ja kiire ajaisi levottomuuden taka-alalle. Tätäkö ihmiset tarkoittavat, kun pubuvat tunteista? Välillä tuntui siltäkin, että jonkinlainen elämänusko palaisi, vaikka aamuöisin hikisissä lakanoissa herätessäni olin vuorenvarma, että olin syvän masennuksen vallassa, ja päätin aina tilata seuraavana päivänä ajan lääkärille, saisin edes nukahtamislääkkeet. (Lundán 2004, 15.)

Lundánin tekstissä kursivoiduille tekstinosille ei osoiteta selkeää funktiota puheen ja ajattelun esittämisessä. Ajatuksia esitetään kursiivilla ja ilman, ja dialogin yhteydessä kursivointia käytetään joskus merkitsemään jonkinlaista sisäistä vastapuhetta.

Olisiko maailman käsite tässä avuksi? Toisen äänen määritteleminen fiktion osamaailmaksi korostaa kursivoidun ja kursivoimattoman Koposen näkökulmaeroa fiktiiviseen todellisuuteen. Koposen ja Koposen maailmat eivät eroa perusrakenteeltaan ja sisällöltään, vaan niiden välillä on asenteellinen ero. Molempien maailmassa Koponen on hieman nahjusmainen, itseään ja läheisiään pettävä 37-vuotias mies, mutta Koposen ja Koposen maailmoissa tähän tosiseikkaan suhtaudutaan eri tavoin. Typografisesti toisistaan eroavien maailmojen välinen suhde myös muuttuu romaanin aikana. Romaanin edetessä Koponen saa enemmän puheaikaa ja muuttuu hyökkäävämmäksi. Kiinnostavaa typografisesti erotetussa kertojan toisessa maailmassa on se, ettei se ole määriteltävissä yhden propositionaalisen asenteen, esimerkiksi pelkäämisen, mukaan. Sekä Koposen että Koposen maailmoissa tieto maailmasta ja kaikki tuohon tietoon liittyvät asenteet ovat läsnä, joskin eri painotuksin. Ero kursivoidun ja kursivoimattoman maailman välillä on lopulta niiden maailmankuvassa, siinä, miten ne tulkitsevat kertojan 
elämäntilanteen. Tässä suhteessa Koposten maailmat asettuvat rinnan lukijan muodostaman tulkinnan kanssa.

Fiktion maailmojen havaitsemisen ja tulkinnan suhdetta pohditaan lisää myöhemmin. Viimeisenä Rinnakkain-romaanin analyysimallina käsitellään seuraavaksi Ryanin ajatusta kerrottavuuden ja fiktion maailmojen moninaistumisen yhteydestä.

Ryanin mukaan tarina on sitä kerrottavampi - siis parempi tarina - mitä useampia mahdollisia fiktiivisen maailman versioita se sisältää tai lukijassaan herättää (Ryan 1991, 157-166). Tämän ajatuksen mukaan kertomus, joka etenee tarinaan osallistuvien yksilöiden odotusten, toiveiden ja suunnitelmien mukaisesti, on vähemmän kiinnostava kuin kertomus, jossa tarinaan osallistuvien yksilöiden toiveet, odotukset ja suunnitelmat risteävät ja toteutuvat tai jäävät toteutumatta yllättävillä tavoilla. Satu Punahilkasta on siis yhtäältä kiinnostava siksi, että Punahilkan yksityisessä uskomusmaailmassa susi on isoäiti, vastoin fiktiivisen todellisen maailman asiaintilaa. Toisaalta sadun kerrottavuutta lisää edelleen se, että suden petomaisessa odotusten maailmassa se saa syödä isoäidin ja Punahilkan ja sillä siisti. Sadun fiktiivisesti toden maailman tuleva asiaintila, jossa metsämies leikkaa saksilla suden vatsan, on tietysti ratkaisevasti ristiriidassa suden odotusmaailman kanssa. ${ }^{10}$ Lopputuloksena on kiinnostava ja kerrottava kertomus. Ryanin ajatus mahdollisten maailmojen moninaistumisesta (diversification of possible worlds) kertomuksen kiinnostavuuden perusteena tuntuu järkevältä.

Ryanin ajatuksen mielekäs hyödyntäminen edellyttää kuitenkin sitä, että kiinnitetään huomiota tarkastelun yleisyyden tasoon. Fiktiivisen maailman jäsenten sisäisten maailmojen analyysi ryöstäytyy käsistä, jos koetetaan yhdistää kertomuksen suuret linjat ja yksityiskohdat. Punahilkasta voisi helposti eritellä lukuisia tilanteita, joissa tarinaan osallistuvien yksilöiden sisäiset maailmat ovat konfliktissa fiktiivisen todellisuuden kanssa ja keskenään. ${ }^{11}$ Voisi väittää, että minkä tahansa kertomuksen sisältämien mahdollisten maailmojen tarkastelu johtaa helposti niin moninaistuneeseen mahdollisten maailmojen verkostoon, että sen analyysi on tulkinnallisesta näkökulmasta liian tarkkaa. Fiktion maailmojen moninaistumisen tutkiminen vaatii tulkinnallista silmää.

Rinnakkain-romaanissa kuvatun parisuhteen kannalta mahdollisten maailmojen perusrakenne on yksilöiden sisäisten maailmojen ja fiktiivisen todellisuuden suhteen melko yksinkertainen. Romaanin fiktiivisesti toden maailman ja pariskunnan toive- ja pelkomaailmojen väliset yhteydet ja konfliktit toki omalta osaltaan motivoivat romaanin lukemista. Päähenkilön ja hänen vaimonsa sisäisten maailmojen välisiä ristiriitoja voitaisiin perinteistä kirjallisuudentutkimuksen kieltä käyttäen kutsua draamalliseksi jännitteeksi. Mahdollisten maailmojen poetiikan avulla keskenään kiinnostavasti ristiriitaisia osamaailmoja voidaan käydä läpi yksityiskohtaisemmin.

Erään Lundánin romaanin keskeisistä ristiriidoista aiheuttaa Koivunotkon asuinalueelle sijoittuvan rivitaloyhteisön naapuriin perustettava asunnottomien tukikoti. 
Tukikodin valmistuminen kytkeytyy romaanissa moniin potentiaalisiin ja aktuaalistuviin osamaailmoihin:

- Koposen ihastus Silja on työharjoittelussa tukikotihankkeessa, ja Koponen pelkää pilaavansa mahdollisuutensa vastustamalla hanketta, mutta

- Koponen toisaalta pääsee romanttiselle kaatopaikkakävelylle Siljan kanssa kiistan vuoksi,

- koivunotkolaiset pelkäävät tukikodin valmistumisen vaikuttavan asuntojen jälleenmyyntiarvoon,

- Koponen pelkää muuttuneensa tai muuttuvansa poroporvariksi, joka potee not-in-my-backyard -syndroomaa,

- tukikotihankkeen järjestäjät toivovat kaavamuutosta,

- Koponen asuu perheineen tukikodissa vesivahinkoremontin aikana,

- Koposen työtön alkoholistinaapuri muuttaa tukikotiin sen valmistuttua.

Ja niin edelleen. Ryanin fiktion maailmojen moninaistumishypoteesin mukaisesti tarkasteltuna tukikodin perustaminen on romaanin tarinan kerrottavuuden kannalta keskeinen tapahtuma: sen ympärille asettuu rykelmäksi fiktion osamaailmoja, jotka ovat ristiriidassa keskenään. Kerrottavuuden kannalta keskeinen tapahtuma on ymmärrettävästi myös temaattisesti kiinnostava. Tukikodin perustaminen liittyy myös kiinteästi romaanin rinnakkaisuus-tematiikkaan, mikä tulee tekstissä suoraan esiin Siljan viedessä Koposta kaatopaikkaekskursiolle:

- [S]ano vielä miks me tehdään se?

Silja katsoi silmiin ja hymyili.

- Huvikseen. Ja koska mä haluan näyttää sulle, että maailmassa monet hyvin erilaiset jutut on pantu vierekkäin eikä taivas oo vielä pudonnut meiän niskaan. (Lundán 2004, 125.)

Yhteys teeman tunnistamisen ja runsaasti fiktion osamaailmoja synnyttävien tapahtuvien välillä on ilmeinen, mutta silti ainakin kahdessa mielessä kiinnostava. Ensinnäkin on luultavaa, että fiktion maailmojen moninaistumisen tarkastelua voisi hyödyntää temaattisessa kirjallisuudentutkimuksessa. Teeman kannalta keskeisiin tapahtumiin kytkeytyvien fiktion maailmojen analyysin avulla voidaan havainnollistaa teoksen tematiikkaa. Kaunokirjallisen teeman ja teoksen tapahtumien synnyttämien mahdollisten maailmojen yhteyksien tarkastelulla voisi olla myös merkitystä kirjallisuudenopetuksen kannalta. Kirjallisuutta voi kenties oppia lukemaan ja ymmärtämään paremmin hahmottamalla kaunokirjalliset kertomukset fiktiivisen todellisuuden ympärille asettuneiksi maailmojen kokoelmiksi.

\section{Lopuksi}

Artikkelin lähtökohta oli tarkastella mahdollisten maailmojen poetiikan mahdollisuuksia deskriptiivisen poetiikan kannalta. Käsittelyn aikana on käynyt ilmi, että hyödyntämällä kertomusten johdonmukaisesti mahdollisiin maailmoihin liittyviä käsittei- 
tä saadaan jonkin verran analyyttista lisäarvoa. Tarkastelemalla Rinnakkain-romaanin maailmojen todentamista oli mahdollista analysoida kerronnan luotettavuutta melko hienojakoisesti. Maailman käsitteen hyödyntäminen analyyttisena metaforana tarjosi uuden näkökulman myös Lundánin romaanin omalaatuiseen puheen ja ajattelun esittämiseen.

Veikko Rantalan $(1990,38)$ mukaan mahdollisten maailmojen semantiikka, kun "sitä sopivasti yleistetään", "antaa [--] välineet käsitellä taideteosten tulkintaan liittyviä ongelmia". Rinnakkain-romaanin kertojan määrittelemien maailmojen analyysi tuo esiin ainakin sen, että mahdollisten maailmojen poetiikka korostaa ja osin myös tekee näkyväksi lukijan tulkinnallista työtä. Fiktion maailmojen ja niiden keskinäisten suhteiden tunnistamisessa (tai konstruoimisessa) todettiin liikuttavan samalla abstraktiotasolla kuin vaikkapa kirjallisten teemojen tunnistamisessa (vrt. van Peer 2002, 263). Tämä on hieman erikoinen havainto - mahdollisten maailmojen poetiikan klassikot, erityisesti Doležel, pitävät kertovaa tekstiä kirjallisuudentutkimuksen ylimpänä auktoriteettina. Mahdollisten maailmojen poetiikka on kuitenkin myös tulkintaa ja tulkinnallista kontekstia korostava tutkimusote.

Fiktion maailmojen analyysissa ja tulkinnassa tekstin suhde reaalimaailmaan on jatkuvan ja välttämättömän pohdinnan kohteena. Sekä Umberto Eco että Doležel (1998, 177-181) käyttävät ensyklopedian käsitettä kuvaamaan sitä tietoa, jota lukijat käyttävät fiktiivisiä maailmoja luodessaan ja täydentäessään. Kognitiotieteellisestä näkökulmasta lukijat hyödyntävät fiktion maailmoihin sukeltaessaan samoja skeemoja ja skriptejä kuin todellisessakin elämässä. Tästä näkökulmasta esimerkiksi Doleželin, Ryanin tai Hermanin (2002) tarjoamat mallit mahdollistavat sekä fiktiivisten kertomusten intensionaalisen rakenteen analyyttisen tarkastelun että analyysin tulosten yhdistämisen kontekstuaaliseen tulkintaan. Se, kuinka hyödyllistä tällainen fiktion maailmojen deskriptiivinen poetiikka on, riippuu lopulta kirjallisuudentutkijoiden kekseliäisyydestä.

Päätän käsittelyni hajamuistoon fiktion maailman hiljattaisesta muotoutumisesta ja siitä, miten todellinen maailma ja fiktioiden todellisuudet yhdistyvät tulkinnassa. Reko ja Tina Lundánin romaanin Viikkoja, kuukausia (2006) kirjailijahahmo kirjoittaa kirjaa loppuun palavasta miehestä:

Kirjoitin henkilöä rakkaudella ja niin rohkeasti kuin suinkin pystyin. Jos en selviäisi tästä hengissä, en ainakaan tässä kirjassa syyllistyisi kirjailijan kuolemansyntiin, totuuden sanomisen pelkoon. (Lundán \& Lundán 2006, 67-68.)

Tämä tekstinkohdan jälkeen romaanin lukemistani hallitsi voimakas tekstuaalinen déjà-vu. Viikkoja, kuukausia sisältää useita yksityiskohtia, jotka liittävät sen Rinnakkainromaaniin. Samoja tai samankaltaisia vuorosanoja eri henkilöiden lausumina, samoja arkielämän tapahtumia liitettynä eri tilanteisiin eri fiktiivissä maailmoissa. Erikoisin näistä yksityiskohdista on se, että molemmissa romaaneissa yksi tai useampi ihminen 
pakenee ahdistustaan sängyn alle. Romaanien fiktiiviset maailmat ovat rinnakkain siten että ne vuotavat toisiinsa. Ontologisten tasojen ja maailmojen välisten rajojen ylittämiset ovat tietysti postmodernistisen kirjallisen leikittelyn perusvälineistöä. Esimerkiksi Robert Cooverin, Thomas Pynchonin tai Antero Viinikaisen teoksissa fiktiiviset ja todelliset henkilöt vierailevat vaivatta itselleen vieraissa fiktiivisissä todellisuuksissa. Lundánien romaanien väliset yhteydet ovat kuitenkin hienovaraisempia: teosten maailmojen välillä liikkuvat pienet tapahtumat, lyhyet vuorosanat ja ohimenevät tunnelmat.

Väitin aiemmin, että Rinnakkain ei erityisesti käsittele maailmojen suhteita. Viikkoja, kuukausia kuitenkin osoittaa väitteen virheellisyyden: yhdessä Lundánien romaanit tulevat käsitelleeksi sekä fiktiivisten maailmojen suhteita että todellisuuden ja fiktion suhdetta. Miten tämä fiktiivisten todellisuuksien kytkeytyminen olisi tulkittava? Kirjailijat välttävät totuuden sanomisen pelkoa kirjoittamalla lukijoilleen maailmoja, joihin totuudet löytyvät todellisuuden ja fiktioiden mahdollisista maailmoista.

\section{Viitteet}

${ }^{1}$ Modaalisen logiikan tai mahdollisten maailmojen semantiikan syntyhistorian kattavaa selvitystä tai sen vaikutusta lingvistiikkaan ja kirjallisuudentutkimukseen on tarpeetonta ja mahdotonta esittää tämän artikkelin puitteissa - kirjallisuudentutkimuksen tarpeisiin soveltuvia yleiskatsauksia ovat esimerkiksi Doležel 1998, Pavel 1986, Ronen 1994 ja Ryan 1991.

Filosofian historiassa mahdollisen maailman käsite liitetään usein Leibnizin ajatteluun: mahdolliset maailmat ovat olemassa Jumalan ajatuksina, ja hyvä, viisas ja johdonmukainen kaikkivaltias on valinnut näistä parhaan toteutettavaksi (esim. Ryan 1991, 16). Käsitettä täsmensivät 1960- ja 1970-luvuilla muiden muassa Saul Kripke ja Jaakko Hintikka siten, että mahdollisesta maailmasta tuli intensionaalisen semantiikan käsite, jonka avulla intensionaalisen merkityksen määrittäminen palautetaan ekstensionaalisen logiikan ilmaisukeinojen piiriin. Kripken muotoilun mukaan mahdollisten maailmojen joukon jäsenet ovat tietyn saavutettavuussuhteen (accessibility relation) mukaisesti keskenään vaihtoehtoisia (Hintikalla relation of alternativeness, Hintikka 1963, 66). (Kripke 1963, 84, 91; referoitu esim. seuraavissa: Pavel 1986, 44-45; Doležel 1998, 12-13.) Kytköksissä olevien mahdollisten maailmojen rakennelma on hyödyllinen modaalisten ilmaisujen merkityksen määrittelemisessä. Lauseiden totuusarvot eivät tällöin määrity yksinomaan suhteessa reaalimaailmaan vaan myös sille vaihtoehtoisiin mahdollisiin maailmoihin. Mahdollisten maailmojen näkökulmasta välttämättömät lauseet ovat tosia kaikissa saavutettavissa mahdollisissa maailmoissa. Mahdolliset lauseet puolestaan ovat tosia vähintään yhdessä saavutettavassa mahdollisessa maailmassa. Lopulta välttämättä epätodet lauseet ovat epätosia kaikissa saavutettavissa mahdollisissa maailmoissa.

Mahdollisten maailmojen merkitys kirjallisuudentutkimukselle on ilmeinen, ainakin jos pitkälti unohdetaan, mitä noilla maailmoilla yritetään modaalilogiikassa saavuttaa. Mahdolliset maailmat liittoutuvat vaivatta kaunokirjallisuuden lukijoissaan synnyttämien mielikuvitusmaailmojen kanssa, ja tuloksena kirjallisuudentutkijoilla pitäisi olla kurinalainen 
sanasto, jolla puhua maailmoista ja niiden välisistä suhteista. Modaalilogiikan käsiteapparaatti ei ole kuitenkaan sellaisenaan sovellettavissa kirjallisuudentutkimukseen. Mahdollisten maailmojen semantiikasta on tehtävä kirjallista, mihin tässäkin artikkelissa pyritään.

${ }^{2}$ Termi on Koskimaan (1999): "possible worlds poetics". Käytän sitä tässä artikkelissa johdonmukaisesti, vaikkei käsite ole vakiintuneessa käytössä. Mahdollisten maailmojen poetiikka tarkoittaa tässä kirjallisuudentutkimusta, joka hyödyntää mahdollisten maailmojen semantiikan käsitteistöä kertomusteoriassa ja kaunokirjallisten kertomusten analyysissa ja tulkinnassa.

${ }^{3}$ Modaalisen logiikan ja kirjallisuuden ja muun taiteentutkimuksen mahdollisten maailmojen tutkimusperinteiden erillisyydestä kertoo hyvin vuonna 1986 järjestetyn Nobel-symposiumin julkaisu Possible Worlds in Humanities, Arts and Sciences (1989). Siinä keskustellaan mahdollisista maailmoista - filosofit keskenään, lingvistit keskenään ja kirjallisuudentutkijat keskenään.

${ }^{4}$ Hermanin tutkimus yhdistää kognitiivista kielentutkimusta ja narratologisia käsitteitä luodakseen käsitteensä "tarinamaailma” (story-world). Tässä mielessä se kiinnittyy vähemmän ilmeisesti modaalisen logiikan mahdollisiin maailmoihin. Fokalisaatiota käsitellessään Herman kuitenkin tukeutuu selkeämmin mahdollisten maailmojen käsitteeseen (Herman 2002, luku 8; vrt. Hägg 2005, luku 8.).

${ }^{5}$ Erityisen ansiokas on McHalen tapa yhdistää maailmojen välisen identifioinnin käsite (transworld identity) postmodernistisen fiktion maailmojen tulkintaan.

6.Tästä on esimerkki myös Raine Koskimaan tutkimus Digital Literature (2000, erit. luku 4), jossa mahdollisten maailmojen semantiikan käsitteistöä käytetään hypertekstikirjallisuuden maailmojen analyysissa ja tulkinnassa.

${ }^{7}$ Erityisesti Mightonin näytelmä havainnollistaa ja pohdiskelee David Lewisin modaalisen realismin ja Umberto Econ fiktiivisten maailmojen teorian eroa. Myös Ryan käsittelee modaalista realismia ja multiversumin käsitteen narratiivisia ja narratologisia implikaatioita Poetics Todayn artikkelissaan "From Parallel Universes to Possible Worlds" (2006). Modaaliseen realismiin liittyvä ajatus siitä, että kaikki ajateltavissa olevat mahdolliset maailmat ovat reaalisesti olemassa, tuntuisi soveltuvan erityisesti kokeelliseen kirjallisuuden tutkimukseen. ${ }^{8}$ Suomennokset SH.

${ }^{9}$ Mahdollisten maailmojen poetiikka on otollinen kohde samoille kontekstualisoiville ja filosofisille vastaväitteille, jotka on suunnattu strukturalistista narratologiaa vastaan. Ei siis olekaan yllättävää lukea postmodernia kertomuksen teoriaa rakennelleen Andrew Gibsonin $(1996,70)$ kritisoivan Pavelin fiktiivisten maailmojen hahmotelmaa sen tarrautumisesta kirjallisuuden referentiaalisuuteen. Jälkistrukturalistisesta näkökulmasta mahdollisten maailmojen teoria on väistämättä ideologinen lähestymistapa. Suohan se, Gibsonin (mts. 89) sanoin, todelliselle maailmalle "ontologisen ensisijaisuuden" suhteessa fiktion sepitteellisiin maailmoihin. Vaikka Gibson ei asiaa laajemmin käsittelekään, voisi olettaa, että jälkistrukturalisti kokee samalla tavoin väkivaltaisena ajatuksen fiktiivisesta universumista, jossa fiktionsisäiset mahdolliset maailmat määrittyvät suhteessa ensisijaiseen, fiktiivisesti todelliseen, maailmaan.

${ }^{10}$ Tässä puhutaan nyt Grimmin veljesten sadun onnellisesta lopusta.

${ }^{11}$ Punahilkan uskomusmaailmassa polulta poikkeaminen, kukkien poimiminen ja linnunlaulun kuunteleminen matkan varrella ei ole vaarallista. Isoäidin uskomusmaailmassa oven takana huhuilee Punahilkka. Punahilkan selitys- tai arvelumaailmat isoäidin suurien 
korvien suhteen jäävät tekstissä esittämättä, mutta kekseliäs lukija sellaiset helposti kehittelisi. Metsämiehen uskomusmaailmassa suden kuorsaus on isoäidin kuorsausta (tämä on juonen kannalta erityisen tärkeä maailmojen välinen konflikti, koska avulias metsämies menee mökkiin juuri pahalta kuulostavalle vanhukselle apua tarjoamaan). Punahilkan pelkomaailmassa hän joutuu jäämään suden sisään pysyvästi. Suden toivemaailmassa se pääsee juoksemaan karkuun, mutta fiktiivisessä todellisuudessa kivet vatsassa koituvat sen kohtaloksi.

\section{Lähteet}

allén, Sture i989 (TOIM.): Possible Worlds in Humanities, Arts and Sciences. Proceedings of Nobel Symposium 65. Berlin - New York: Walter de Gruyter.

CUller, JONATHAN I988: Framing the Sign. Criticism and Its Institutions. Norman: Univ. Of Oklahoma Press.

CURrIe, MARK 2008: About Time. Narrative, Fiction and the Philosophy of Time. Edinburgh: Edinburgh Univ. Press.

DOLEŽEL, Lubomír I979: Extensional and Intensional Narrative Worlds. Poetics 8, 193-211.

Doležel, Lubomír i983: Proper Names, Definite Descriptions and the Intensional Structure of Kafka's The Trial. Poetics 12, 511-526.

DOLEŽEl, Lubomír i 998: Heterocosmica. Fiction and Possible Worlds. Baltimore and London: Johns Hopkins Univ. Press.

FLUdERnik, MONika 200I: New Wine in Old Bottles? Voice, Focalization, and New Writing. New Literary History 32, 619-638.

FOŘT, вонUмil 2006: Are Fictional Worlds Really Possible? A Short Contribution to Their Semantics. Style 40:3, 189-197.

GIBSON, ANDREW I996: Towards a Postmodern Theory of Narrative. Edinburgh: Edinburgh Univ. Press.

HERMAN, DAVID I999: Introduction: Narratologies. Narratologies: New Perspectives on Narrative Analysis. Toim. David Herman. Columbus: Ohio State Univ. Press.

HERMAN, DAVID 2002: Story Logic: Problems and Possibilities of Narrative. Lincoln: Univ. of Nebraska Press.

Hintikka, JaAkKo i963: The Modes of Modality. Acta Philosophica Fennica 16, 65-79. Hutcheon, LINDA I 996: The Politics of Impossible Worlds. Fiction Updated. Theories of Fictionality, Narratology, and Poetics. Toim. Calin-Andrei Mihailescu ja Walid Hamarneh. Toronto: Univ. of Toronto Press.

HÄGG, SAMULI 2005: Narratologies of Gravity's Rainbow. Joensuu: Joensuun yliopistopaino.

JEDLiČKovÁ, ALICE 2006: From Otherworldliness and a Two-World Scheme to "Hete- 
rocosmica": A Visit to a Museum With Cortázar and Nabokov. Style 40:3, 258-271.

KoskimaA, RaIne I 999: Possible Worlds in Literary Theory. Poetics Today 20:1, 133-138. KOSKIMAa, RaINe 2000: Digital Literature. From Text to Hypertext and Beyond. <http:// www.cc.jyu.fi/ - koskimaa/thesis/thesis.shtml> (30.6.2008)

Kripke, Saul A. 1963: Semantical Considerations on Modal Logic. Acta Philosophica Fennica 16, 83-94.

KRIPKE, SAUl A. I980: Naming and Necessity. Cambridge: Harvard Univ. Press.

LUNDÁN, REKO 2004: Rinnakkain. Helsinki: WSOY.

LUNDÁN, REKO \& LUNDÁN, TINA 2006: Viikkoja, kuukausia. Helsinki: WSOY.

mChale, BRian 1987: Postmodernist Fiction. New York: Methuen.

MCHALE, BRIAN I 992: Constructing Postmodernism. New York: Routledge.

MChale, BRIAn I 994: Whatever Happened to Descriptive Poetics? The Point of Theory.

Practices of Cultural Analysis. Toim. Mieke Bal ja Inge E. Boer. Amsterdam: Amsterdam Univ. Press.

MIETtinen, RAUNO 2005: Hullujen naisten kanssa ullakolla. Kertojan luotettavuus ja tulkinta Charlotte Perkins Gilmanin novellissa The Yellow Wallpaper. Kertomus ja mieli. Uusia (ja vanhoja) näkökulmia tajunnan esittämiseen kertomakirjallisuudessa. Toim. Maria Mäkelä ja Pekka Tammi. Tampere: Tampereen yliopiston taideaineiden laitos. OLSON, GRETA 2003: Reconsidering Unreliability: Fallible and Untrustworthy Narrators. Narrative 11:1, 93-109.

pavel, thomas G. I986: Fictional Worlds. Cambridge: Harvard Univ. Press.

PHELAN, JAMES 2005: Living to Tell about It. A Rhetoric and Ethics of Character Narration. Ithaca and London: Cornell Univ. Press.

RANTALA, VEIKKO I990: Elokuvakerronta ja elokuvan mahdolliset maailmat. Synteesi 1/1990, 34-43.

rimmon-kenan, Shlomith i983: Narrative Fiction. Contemporary Poetics. London: Methuen.

RONen, RUTH I994: Possible Worlds in Literary Theory. Cambridge: Cambridge Univ. Press.

ryan, Marie-laure i 99i: Possible Worlds, Artificial Intelligence, and Narrative Theory. Indiana: Univ. of Bloomington \& Indianapolis Press.

RYAN, MARIE-LaUre I 992: Possible Worlds in Recent Literary Theory. Style 26, 528-554. RYAN, MARIE-LAURE 2006: From Parallel Universes to Possible Worlds: Ontological Pluralism in Physics, Narratology, and Narrative. Poetics Today, 27: 4, 633-674.

Traill, Nancy H. I996: Possible Worlds of the Fantastic. The Rise of the Paranormal in Literature. Toronto: Univ. of Toronto Press.

VAN PEer, WILlie 2002: Where Do Literary Themes Come From? Thematics. Interdisciplinary Studies. Toim. Max Louwerse. Philadelphia: John Benjamins. 